\title{
The Application of the Mutagen Nitrous Acid to Improve the Free Living Nitrogen Fixation Ability of Azotobacter spp.
}

\author{
Rayan M. Faisal \\ Department of Biology \\ College of Science \\ University of Mosul
}

Email: rayanmazin@yahoo.com

(Received 18/7/2012 ; Accepted 26/8/2012)

\begin{abstract}
Three previously isolated Azotobacter spp. were obtained from a previous study and their identification and sensitivity were confirmed to seven different antibiotics. They showed resistance against chloramphenicol (C15) and nalidixic acid (NA30) but all were sensitive to ampicillin (AM50), tetracycline (TE15), cefalexin (CL30), rifamycin (RA10) and streptomycin (S50). Plasmid DNA electrophoresis revealed that isolates contain a single band of DNA with a m.wt. of $14 \mathrm{~kb}$. The isolates were mutagenized by nitrous acid at a concentration of $0.05 \mathrm{M}$ for 10 min which gave mutations at a percentage of (12-21\%), (8$18 \%)$ and (2-8\%) towards (C15), (NA30) and (S50) respectively, (6-20\%) of the mutagenized isolates showed an ability to grow at $42^{\circ} \mathrm{C}$ and $(18 \%)$ of the isolate $\mathrm{A} 3$ showed inability to fix nitrogen. Three mutagenized colonies from each isolate were selected depending on its mutation frequency, all were able to fix nitrogen, had the ability to grow on $42^{\circ} \mathrm{C}$ and carried one or more antibiotic mutation. The amount of ammonia excreted in $\mu \mathrm{g} / \mathrm{ml}$ at 28,37 and $42^{\circ} \mathrm{C}$ was recorded at intervals of three days for 15 days for the three wild type and all selected mutagenized isolates. The best amount of ammonia excreted was at $37^{\circ} \mathrm{C}$ at the $12^{\text {th }}$ day of incubation for the mutagenized isolate A2, 15 that was $12.0,12.5$ and $7.5 \mu \mathrm{g} / \mathrm{ml}$ at 28,37 and $42^{\circ} \mathrm{C}$ respectively. All mutagenized isolates had the ability to excrete ammonia at $42^{\circ} \mathrm{C}$ at a percentage of $(4.5-7.5) \mu \mathrm{g} / \mathrm{ml}$ therefore these mutagenized isolates could be used as bio-fertilizers in Iraqi soils that are affected to such temperatures for many periods of the year.
\end{abstract}

Keywords: Azotobacter, chemical mutagenes, bio-fertilizer.

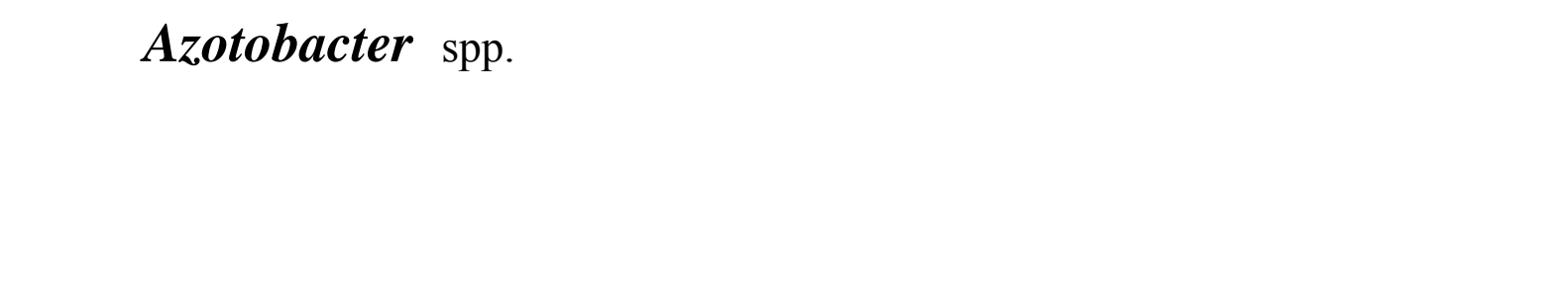

مُ الحصول على ثلاث عزلات من جرثومة .Azotobacter spp من درلسةسابقة، لختبرت جسلسيتها لسبعة مضادات حيوية ولوظظ ان الجمبع مقاومة للكلورلمفينيكول وحلمض النالمسيك ومسلسة تجاله 
المبسلين والتترلسايكلين وللسفالمسين والريفلمليسين وللستربتومليسن. لظهرت نتائج الترحل الكهربائي

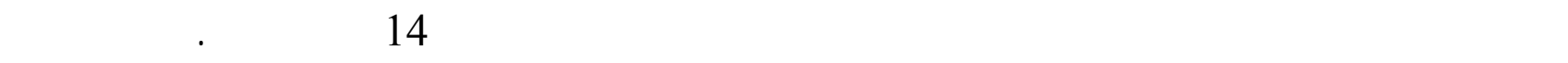

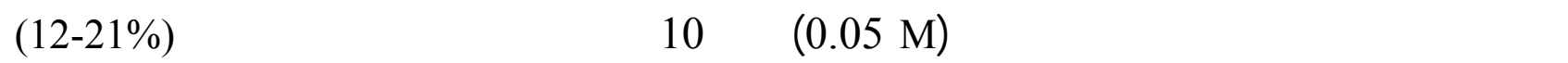
و (18\%-8) و (8\%-2) تجاه المضادات الكلورلمفينيكل وحلمض النالكسيك وللستربتومليسن على التوالي. كما لوظظ نسبة ظفير (6-20\%) لمستعمرات مقاومة للحرارة 42\%م وكانت نسبة الظفير في مورثثات تشبيت

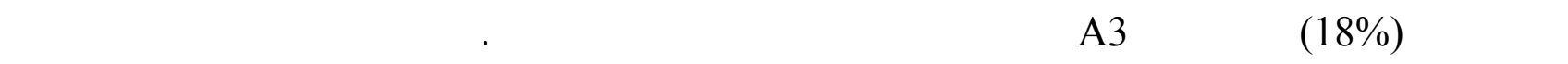

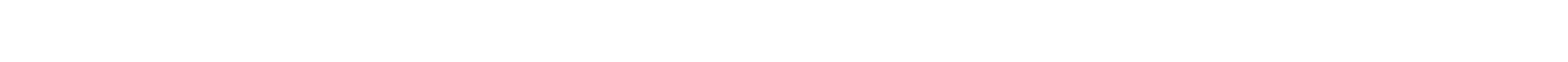

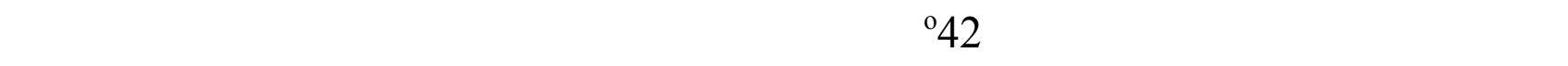

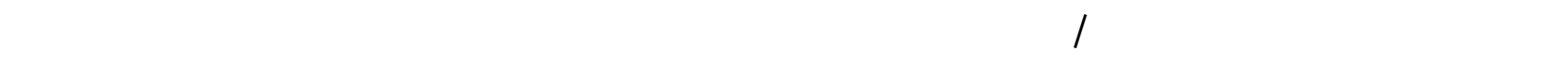

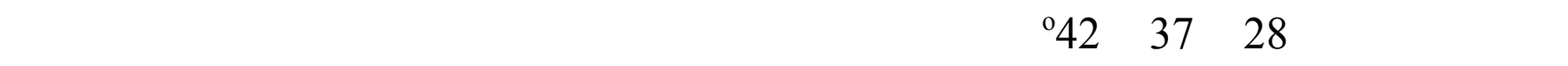

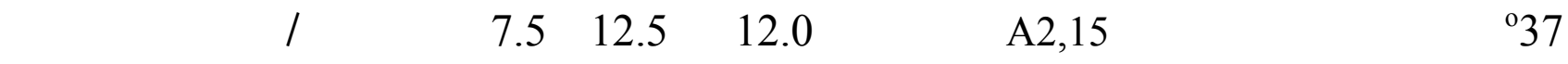

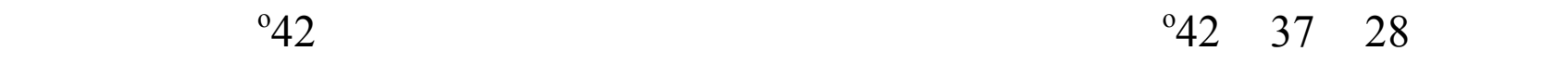

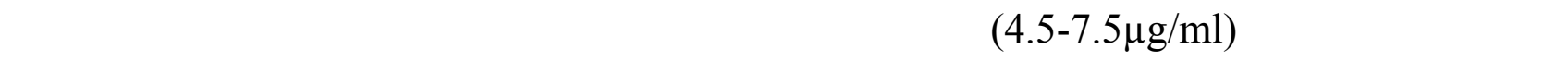

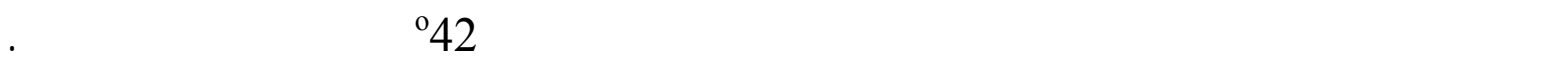

الكامل الدالة : .Azotobacter spp.، المطفرات الكيمياوية، المخصبت البايولوجية.

\section{INTRODUCTION}

Soil contains a variety of micro-organisms included bacteria that can be found in any natural ecosystem. Micro-organisms play an important role on nutritional chains which are an important part of the biological balance in the life in our planet, where bacteria are essential for the closing of nutrient and geochemical cycles such as the carbon, nitrogen, sulfur and phosphorous cycle. Without bacteria, soil will not be fertile and organic matter will accumulate within a short time (Bahig et al., 2008). Nitrogen fixation can be considered as one of the most interesting microbial activity as it makes the recycling of nitrogen on earth possible and gives a fundamental contribution to nitrogen homeostasis in the biosphere. Among the free-living nitrogen fixing bacteria are those belonging to genus Azotobacter spp. play a remarkable role, being broadly dispersed in different environments, such as soil, water and sediments (Aquilanti et al., 2004). Azotobacter spp. has recently been developed as a crop inoculants for cereals, oil seeds, cotton and vegetables because of its ability to produce plant growth regulators, siderophores and antimicrobial substances as well as excreting ammonia (Garg et al., 1997). Attempts are being made all over the world to genetically improve this agronomically important bacterium for different charecters (Lakshminarayana,1993).

The aim of the currnet study is to obtain mutated strains of Azotobacter spp. capable of fixing nitrogen at $42^{\circ} \mathrm{C}$ that can be used as a biofertilizer in Iraqi soils which are affected to such high temperatures in many periods of the year. 


\section{Azotobacter spp. collection}

\section{MATERIALS AND METHODS}

Azotobacter spp. isolates were obtained from the study of Hamdoon (2012). They were isolated from different soil samples from different loci in Nineveh governorate.

\section{Antibiotic susceptibility test}

Antibiotic resistance of Azotobacter spp. isolates towards Ampicillin $(50 \mu \mathrm{g} / \mathrm{ml})$, Chloramphenicol $(15 \mu \mathrm{g} / \mathrm{ml})$, Tetracycline $(15 \mu \mathrm{g} / \mathrm{ml})$, Cefalexin $(30 \mu \mathrm{g} / \mathrm{ml})$, Rifamycin $(10$ $\mu \mathrm{g} / \mathrm{ml})$, Streptomycin $(50 \mu \mathrm{g} / \mathrm{ml})$ and Nalidixic acid $(30 \mu \mathrm{g} / \mathrm{ml})$ was performed according to Grant and Pittard (1974).

\section{Plasmid isolation and electrophoresis}

Plasmid DNA was isolated according to Birnboim and Doly (1979). The isolated plasmid DNA from the three Azotobacter spp. isolates which were runed in a $0.8 \%$ agarose gel according to Aabo et al., (1995) with a DNA ladder containing 18 bands ranging from $100 \mathrm{bp}-10,000 \mathrm{bp}$.

\section{Mutagenesis by nitrous acid}

Freshly prepared nitrous acid was used at the concentration of $0.05 \mathrm{M}$ to mutate Azotobacter spp. isolates for two periods 10 and 20 minutes according to Miller (1972). Master plates containing 100 colonies for each isolate were prepared in order to detect mutations against antibiotic understudy, the ability to grow at $42^{\circ} \mathrm{C}$ and the ability to fix nitrogen.

\section{Detection different mutations}

Brown - nitrogen free medium was prepared and used according to Brown et al., (1962) to indicate the ability of the isolates to fix nitrogen, mutated percentage of colonies incapable to grow on this medium was also recorded.

An Antibiotic resistant mutation percentage against antibiotics was recorded after transferring the master plate of each isolate to all antibiotic media understudy.

The percentage of mutated isolates capable of growing at $42^{\circ} \mathrm{Cwas}$ also recorded after transferring the master plates of each isolate to nutrient agar and incubating them for 72 hour at $42^{\circ} \mathrm{C}$.

\section{Production and estimation of ammonia}

The ability of ammonia excretion by the three wild types and some mutated isolates of Azotobacter spp. understudy was checked at $28^{\circ} \mathrm{C}, 37^{\circ} \mathrm{C}$ and $42^{\circ} \mathrm{C}$ according to Chaney and Marbach (1962) by inoculating them in a flask containing $50 \mathrm{ml}$ of Brown $-\mathrm{N}$-free broth at different temperature of $(28,37$ and 42$){ }^{\circ} \mathrm{C}$. Two $\mathrm{ml}$ of aliquots was removed at regular intervals of 3 days centrifuged at $10,000 \mathrm{rpm}$ for 30 minutes and the ammonia which released in the supernatant was estimated.

One $\mathrm{ml}$ of the supernatant was mixed with $2.5 \mathrm{ml}$ of reagent $\mathrm{A}$ (phenol $50 \mathrm{~g} / \mathrm{L}$ and sodium nitroprusside $0.25 \mathrm{~g} / \mathrm{L}$, diluted five times) and $2.5 \mathrm{ml}$ of reagent B (sodium hydroxide $25 \mathrm{~g} / \mathrm{L}$ and sodium hypochlorite $2.1 \mathrm{~g} / \mathrm{L}$, diluted five times). The developing color appeared after 30 minutes by shaking and their absorbance was measured at $625 \mathrm{~nm}$ against a reagent blank using spectrophotometer. Ammonium sulfate was used as a standard and results were expressed in $\mu \mathrm{g}$ of ammonia released per $\mathrm{ml}$ of supernatant of culture. 


\section{RESULTS AND DISCUSSION}

\section{Antibiotic susceptibility}

Antibiotic resistance of the three Azotobacter spp. isolates understudy was checked towards seven different antibiotics and the results are shown in Table (1).

Table 1: Antibiotic resistance pattern of Azotobacter spp. isolates understudy

\begin{tabular}{|c|c|c|c|c|c|c|c|}
\hline \multirow{2}{*}{ Isolates } & \multicolumn{7}{|c|}{ Antibiotics } \\
\cline { 2 - 9 } & AM(50) & C (15) & TE(15) & CL(30) & RA(10) & S(50) & NA(30) \\
\hline A1 & $\mathrm{S}$ & $\mathrm{R}$ & $\mathrm{S}$ & $\mathrm{S}$ & $\mathrm{S}$ & $\mathrm{S}$ & $\mathrm{R}$ \\
\hline $\mathrm{A} 2$ & $\mathrm{~S}$ & $\mathrm{R}$ & $\mathrm{S}$ & $\mathrm{S}$ & $\mathrm{S}$ & $\mathrm{S}$ & $\mathrm{R}$ \\
\hline $\mathrm{A} 3$ & $\mathrm{~S}$ & $\mathrm{R}$ & $\mathrm{S}$ & $\mathrm{S}$ & $\mathrm{S}$ & $\mathrm{S}$ & $\mathrm{R}$ \\
\hline
\end{tabular}

As shown in Table (1), all isolates were resistance to C15 and NA30 and no resistance towards other antibiotics understudy was detected. The resistance of Azotobacter spp. towards antibiotics has been studied from several researchers as Saitia et al., (1998) Who found that antibiotic resistance towards AM50, C15, NA30, S50, TE15 and RA10 were encoded on plasmids and chromosomal genes. Maia et al., (1988) found plasmids in 6 isolates only of 32 Azotobacter spp. examined which contained a single plasmid or multiple plasmids. The gel electrophoresis of plasmid DNA of our isolates showed that they all contained a single band of plasmid of a m. wt. of $14 \mathrm{~kb}$ as shown in Plate (1) this may reflect the poor resistance to antibiotics in our isolates and that these plasmids could not be for antibiotic resistance as Robson et al., (1984) cured 8 Azotobacter spp. isolates containing plasmids and he obtained cure cells had no differences in nitrogen fixation, carbon utilization, heavy metal and antibiotic resistance, therefore he indicated that previously mentioned characters were chromosomal. The poor resistance towards antibiotics in our isolates also could be due to the exposure to elevated temperatures during many periods of the years in Iraqi soil. Further studies in our isolates must be obtained to identify the specific role of these plasmids. 


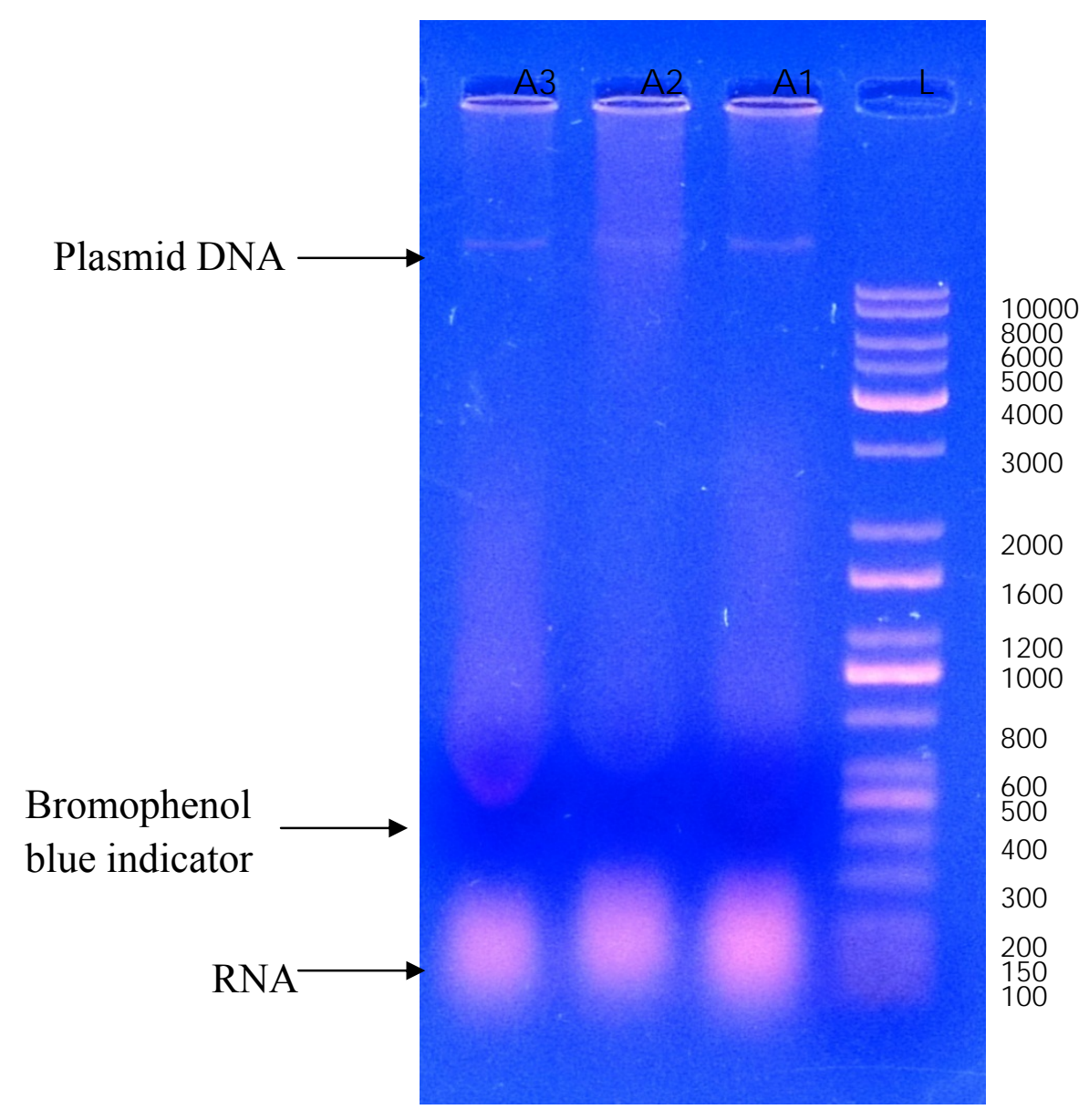

Plate 1: plasmid DNA electrophoresis of Azotobacter spp. isolates

\section{Mutagenesis of Azotobacter spp. isolates}

Nitrous acid at the concentration of $0.05 \mathrm{M}$ for 20 minutes showed a lethal effect as no colonies appeared after this treatment, this was also noticed by Faisal (2003) as he used the same concentration to mutate Pseuudomonas isolates which belong to the same Family with Azotobacter spp. and found the lethal point after 20 minutes. Using the same concentration for 10 minutes gave a lethal percentage of 30.6, 33.4 and 28.5 for the isolates A1, A2 and A3 respectively. Mutations in antibiotic resistance, ability to grow on $42^{\circ} \mathrm{C}$ and the ability to fix nitrogen was also observed as illustrated in Table (2).

Table 2: Mutagenic effect of Nitrous acid on Azotobacter spp. isolates

\begin{tabular}{|c|c|c|c|c|c|}
\hline \multirow{3}{*}{$\begin{array}{c}\text { Isolate } \\
\text { number }\end{array}$} & \multicolumn{5}{|c|}{ Percentage of Mutations towards } \\
\hline & \multicolumn{3}{|c|}{ Antibiotics resistance } & \multirow{2}{*}{$\begin{array}{c}\text { Ability to } \\
\text { grow on } \\
42^{\circ} \mathrm{C}\end{array}$} & \multirow{2}{*}{$\begin{array}{l}\text { Uncapability } \\
\text { to fix } \mathrm{N}_{2}\end{array}$} \\
\hline & $\mathrm{C}(15)$ & NA(30) & $\mathrm{S}(50)$ & & \\
\hline A1 & 12 & 18 & 6 & 6 & 0 \\
\hline $\mathrm{A} 2$ & 14 & 16 & 8 & 20 & 0 \\
\hline A3 & 21 & 8 & 2 & 16 & 18 \\
\hline
\end{tabular}


As shown in Table (2), a percentage of (2-8)\% of antibiotic resistance to $\mathrm{S}(50)$ occurred from the sensitive isolates of Azotobacter spp. as results of nitrous acid mutagenesis. This was also observed by Goodgal and Postel (1965) who used nitrous acid as in vitro mutagen to obtain streptomycin resistant mutations from sequences of DNA transformed to $H$. influenza and showed a normal expression and the generation of resistant mutations to streptomycin from sensitive isolates unlike other sensitive antibiotics tested could be due to the easy formation of resistant mutations to this antibiotic by simple point mutation in the rrs gene that generates an altered site of action in the bacterial ribosome that streptomycin cannot bind (Brooks et al., 2007). Table 2 shows the occurrence of mutations in C (15) and NA (30) resistance genes at a percentage between (12-21\%) and (8-18\%) respectively. This may refer to the ability of nitrous acid to enhance mutations in Azotobacter spp. isolates which were confirmed by the deamination of the $\mathrm{NH}_{2}$ group of adenine and cytosine to an ether group, thus altering the base pairing from A-T to G-C (Dale and Park, 2010).

As shown in Table (2), non-nitrogen fixing mutants have been detected in the isolate A3 at a percentage of $18 \%$ and this high percentage may be due to the high number of genes involved in nitrogen fixation therefore mutation in one may harm the whole process Jacobson et al., (1989) determined a 28,793 bp DNA sequence of a region from the A.vinelandi genome that includes and flanks the nitrogenase structural gene region, which involved 15 nif- specific genes and 12 other potential genes whose expression could be subject to nif-specific regulation, these potential genes do not encode products that are structurally related to the identified nif-specific gene products. 11 of their promoters were identified and 9 of them showed $A+T$ rich regions, which therefore can be mutated by nitrous acid used under study. Jung and Kwon, (2008) found that nitrogen fixation can be inhibited due to the presence of small RNA (sRNA) that play an important regulatory role, turning the gene on and off in response to stress signals and environmental changes. These genes can shut down the expression of iron-containing proteins (as Mo-fe protein used in nitrogenase) when iron is limiting leaving more iron available for proteins crucial for growth and survival, this is encoded by the gene arr F that presents in a single copy in A.vinelandi so mutation in this gene can have effects on nitrogen fixation. On the other hand, no mutations to $\mathrm{N}$-fixation have been occurred in the isolates A1 and A2. This may refer to the efficient repair system in these isolates or due to silent mutations or generating more efficient nitrogen fixing isolates that will be seen in the next experiment. Segura and Espin, (1998) isolated a mutation in pst $\mathrm{P}$ gene in A.vinelandi that lacked the ability to fix nitrogen with $10 \mathrm{mM}$ glucose as a carbon source and they found that this gene was responsible for protecting the nitrogenase from oxygen as this isolate grew on the same media when they lowered the oxygen concentration.

Table (2) also shows the occurrence of temperature resistance mutants capable to grow at $42^{\circ} \mathrm{C}$ at a percentage of $(6-20) \%$ unlike the original isolates. Our results are compatible with Mittal et al., (2011) as he found that all of his A.chroococcum isolates grew and excreted ammonia at $30^{\circ} \mathrm{C}$ but not at $42^{\circ} \mathrm{C}$ but he isolated spontaneously mutated isolates resistant to methyl ammonium chloride that excreted ammonia at $42^{\circ} \mathrm{C}$ and $37^{\circ} \mathrm{C}$. Mutagenesis can lead to temperature sensitive mutations as Benemann et al., (1971) obtained temperature sensitive nitrogen fixation mutants of A.vinelandi by the chemical mutagen nitrosoguanidine, these mutants were unable to fix $\mathrm{N}_{2}$ at $39^{\circ} \mathrm{C}$ and he explained 
this result by the production of some temperature- sensitive protein involved in nitrogen fixation.

\section{Estimation of excreted ammonia by mutagenized Azotobacter spp.}

Three selected mutagenized isolates from each Azotobacter spp. isolate understudy were chosen depending on mutation frequency. The selected mutagenized isolates were capable to grow on $42^{\circ} \mathrm{C}$, carried one or more antibiotic resistance mutations and were capable to fix nitrogen. The amount of ammonia excreted from the isolates was measured as an indirect measurement for nitrogenase activity which has been used by many researchers (Carpa et al., 2010). The amount of ammonia in $\mu \mathrm{g} / \mathrm{ml}$ of each isolate and its mutants is shown in Table 3. As shown in Table (3) all isolates and mutants showed the highest excretion of ammonia on $12^{\text {th }}$ day and the excretion decreased on the $16^{\text {th }}$ day at all temperatures used understudy, as normally nitrogenase causes ammonia to be formed and this consequently represses further nitrogenase synthesis until the ammonia is depleted (Gordon and Brill, 1972). Our results are compatible with Mittal et al., (2011) who found that the best excretion of ammonia in A. chroococcum isolates was on the $12^{\text {th }}$ day of incubation as he explained that the release of ammonia occurs after the cells have reached the stationary phase and the best excretion was at $37^{\circ} \mathrm{C}$ as Rajakumar and Lakshmanan, (1995) found that strains of $A$. chroococcum isolated from temperate region have optimum temperature of $20-25^{\circ} \mathrm{C}$ for growth whereas strains isolated from tropical regions have optimum temperature of $30-35^{\circ} \mathrm{C}$.

The mutant isolates A2,15 showed the highest ammonia excretion as it excreted 12.0, 12.5 and $7.5 \mu \mathrm{g} / \mathrm{ml}$ ammonia followed by the mutant isolate A1,43 as it excreted 10.5, 7.0 and $3.5 \mu \mathrm{g} / \mathrm{ml}$ at the $12^{\text {th }}$ day of incubation to the three temperatures used respectively these amounts were higher from the wild type of each mutant isolate, this may express the successful mutagenesis of nitrous acid towards Azotobacter spp. isolates as nitrous acid has been used by John and Nampoothiri, (2008) to obtain mutants of Lactobacillus delbrueckii that improved increase lactic acid productivity, acid tolerance and sugar tolerance. The mutants also showed better growth rate and lesser generation time than the wild type. The increase in ammonia excretion could be due to point mutations formed by nitrous acid in the promoter of Nif genes as Hirose et al., (1983) found that single transversion point mutations induced by nitrous acid in the TATA box region which is the core of the promoter of the fibroin gene, can increase the promoter activity. 
Table 3: Ammount of ammonia excreted in $\mu \mathrm{g} / \mathrm{ml}$ of Azotobacter spp. wild type and mutagenized isolates at different temperatures

\begin{tabular}{|c|c|c|c|c|c|c|c|c|c|c|c|c|c|c|c|}
\hline \multirow[b]{2}{*}{ Isolate } & \multicolumn{5}{|c|}{$\mu \mathrm{g}$ ammonia excreted at $28^{\circ} \mathrm{C}$} & \multicolumn{5}{|c|}{$\mu g$ ammonia excreted at $37^{\circ} \mathrm{C}$} & \multicolumn{5}{|c|}{$\mu g$ ammonia excreted at $42^{\circ} \mathrm{C}$} \\
\hline & 3 days & 6 days & 9 days & $\begin{array}{c}12 \\
\text { days }\end{array}$ & $\begin{array}{c}15 \\
\text { days }\end{array}$ & 3 days & 6 days & 9 days & $\begin{array}{c}12 \\
\text { days }\end{array}$ & $\begin{array}{c}15 \\
\text { days }\end{array}$ & 3 days & 6 days & 9 days & $\begin{array}{c}12 \\
\text { days }\end{array}$ & $\begin{array}{c}15 \\
\text { days }\end{array}$ \\
\hline A1 & 0.0 & 0.0 & 3.0 & 6.5 & 3.0 & 1.0 & 1.5 & 5.0 & 7.0 & 3.5 & 0.0 & 0.0 & 0.0 & 0.0 & 0.0 \\
\hline $\mathrm{A} 1,40$ & 0.0 & 0.0 & 2.0 & 6.0 & 2.0 & 0.5 & 0.5 & 4.0 & 6.5 & 3.0 & 0.0 & 0.6 & 2.5 & 5.5 & 3.0 \\
\hline $\mathrm{A} 1,43$ & 0.0 & 1.0 & 4.0 & 10.5 & 3.5 & 1.0 & 1.5 & 5.0 & 7.0 & 4.0 & 0.0 & 0.5 & 4.0 & 7.0 & 3.5 \\
\hline $\mathrm{A} 1,45$ & 0.0 & 0.8 & 3.5 & 6.0 & 2.0 & 0.5 & 0.5 & 3.5 & 6.0 & 4.0 & 0.0 & 0.5 & 3.5 & 5.0 & 2.5 \\
\hline A2 & 0.0 & 0.8 & 3.5 & 7.5 & 3.5 & 0.2 & 0.2 & 5.0 & 6.5 & 4.5 & 0.0 & 0.0 & 0.0 & 0.0 & 0.0 \\
\hline $\mathrm{A} 2,9$ & 0.0 & 0.4 & 2.5 & 5.5 & 2.0 & 0.4 & 0.4 & 4.0 & 4.5 & 3.0 & 0.0 & 0.1 & 2.5 & 4.5 & 2.5 \\
\hline $\mathrm{A} 2,14$ & 0.0 & 0.4 & 2.5 & 5.5 & 2.5 & 0.2 & 0.2 & 4.5 & 6.0 & 5.0 & 0.0 & 0.4 & 4.5 & 6.0 & 3.5 \\
\hline $\mathrm{A} 2,15$ & 0.0 & 2.0 & 4.5 & 12.0 & 4.0 & 1.0 & 1.0 & 7.0 & 12.5 & 7.0 & 0.0 & 0.1 & 2.0 & 7.5 & 3.5 \\
\hline A3 & 0.0 & 0.0 & 2.5 & 4.5 & 2.0 & 0.5 & 0.5 & 3.5 & 6.5 & 5.0 & 0.0 & 0.0 & 0.0 & 0.0 & 0.0 \\
\hline $\mathrm{A} 3,43$ & 0.0 & 0.0 & 2.0 & 4.0 & 2.0 & 0.8 & 0.5 & 3.0 & 6.0 & 4.0 & 0.0 & 0.2 & 0.8 & 4.5 & 2.5 \\
\hline $\mathrm{A} 3,46$ & 0.0 & 0.4 & 3.5 & 10.5 & 3.5 & 0.8 & 0.8 & 3.5 & 7.0 & 4.5 & 0.0 & 0.1 & 2.0 & 6.0 & 3.0 \\
\hline $\mathrm{A} 3,47$ & 0.0 & 0.0 & 1.5 & 4.0 & 2.0 & 0.2 & 0.2 & 3.0 & 6.5 & 4.0 & 0.0 & 0.5 & 1 & 5.5 & 2.5 \\
\hline
\end{tabular}


Faisal, R. (2003). Determination of Transposition Property in Antibioticp. Resistance Genes of Pseudomonas aeruginosa and the In vivo and In vitro Effects of Some Chemical Mutagens on Antibiotic Resistance Genes, M.Sc. Thesis, College of Education, Mosul University.

Garg, F.C.; Bharati, R. ; Sharma, P.K. (1997). Isolation of antibiotic- sensitive mutants of Azotobacter chroococcum by the treatment with ascorbic acid, letters in applied microbiology, 24, 136-138.

Goodgal, S. ; Postel, E. (1965). Nitrous acid mutation of transforming DNA: Consideration of mode of action, Science, 148, 1095-1097.

Gordon, J. ; Brill, W. (1972). Mutants that produce nitrogenase in the presence of ammonia, Proc. Nat. Acad. Sci., 69, 3501-3503.

Grant, A. ; Pittard, J.(1974). Incompability reaction of R plasmids isolated from Escherichia coli of animal origin. J. Bacteriol., 120, 185-188.

Hill, S. (1978). Factors influencing the efficiency of nitrogen fixation in free-living bacteria, Ecological bulletins ,26, 130-136.

Hirose, S. ; Takeuchi, K. ; Hori, H. ;Hirose, T. ; Inayama,S.; Suzuki, Y. (1983). Contact points between transcription machinery and the fibroin gene promoter deduced by functional tests of single-base substitution mutants, Biochemistry, 81, 1394-1397.

Jacobson, M.; Brigle, K.; Bennett, L.; Setterquist, R.; Wilson, M.; Cash, V.; Beynon, J.; Newton, W. ; Dean, D. (1989). Physical and genetic map of the major nif gene cluster from Azotobacter vinelandi. J. Bacteriol., 171, 1017-1027.

John, R. ; Nampoothiri, K. (2008). Strain improvement of Lactobacillus delbrueckii using nitrous acid mutation for L- lactic acid production. World J. Microbiol. Biotechnol., 24, 3105-3109.

Jung, Y. ; Kwon, Y. (2008). Small RNA Arr F regulates the expression of sod B and Fes II Genes in Azotobactervinelandi, Current Microbiology, 57, 593-597.

Lakshminarayana, K. (1993). Influence of Azotobacter on nitrogen nutrition of plants and crop productivity, proceeding of the Indian national science academy B59, 303308.

Lou, J. ; Moshiri , F. ; Johnson, M. ; Lafferty , M.; Sorkin , D.; Miller , A.; Maier, R. (1999). Mutagenesis studies of the FeSII protein of Azotobacter vinelandi nitrogenase from : Roles of Histidine and Lysine residues in the protection of nitrogenase from oxygen damage, Biochem., 38, 5563-5571.

Maia, M.; Sanchez, J. ; Vela, G. (1988). Plasmids of Azotobacter vinelandi. J. Bacteriol., 170, 1984-1985.

Miller, J.H. (1972). "Experiments in Molecular Genetics". Cold spring harbor laboratory, U.S.A.466 p.

Mittal, A.; Yadav, A.; Singh, G.; Anand, R. ; Aggarwal, N. (2011). Comparative nitrogen fixation by mesophilic (HTS) vis- a- vis thermo tolerant mutants (HTR) of Azotobacterchroococcum at high temperature and their effect on cotton biomass. Jundishapur J. Microbiol., 4, 105-114.

Rajakumar, K. ; Lakshmanan, M. (1995). Influence of temperature on the survival and nitrogen fixating ability of Azotobacter chroococcum. Indian J. Microbiol., 35, 2530. 
Robson, R.; Chesshyre, J.; Wheeler, C.; Jones, R.; Woodley, P. ; Post gate, J. (1984). Genome size and complexity in Azotobacter chrococcum. J. General Microbiology, 130,1603-1612.

Saitia, S.; Narula, N. ; Lakshminarayana, K. (1998). Nature and role of plasmids in Azotobacter chrococcum. Biotechnology Letters, 11, 713-716.

Segura, D. ; Espin, G. (2006). Mutational inactivation of a Gene Homologus to Escherichia coli pst $\mathrm{P}$ affects Poly- $\beta$ - hydroxybutyrate accumulation and nitrogen fixation in Azotobacter vinelandi. J. Bacteriol., 180, 4790-4798.

Terzaghi, B. (1980). A method for the isolation of Azotobacter spp. mutants derepressed for Nif. J. General. Microbiol., 118, 275-278. 